\title{
How to improve accountability of fixed assets of local government?
}

\author{
Sri Rahayu*; Yudi; Rahayu \\ Faculty of Economics and Business, Universitas Jambi, Indonesia \\ *To whom correspondence should be addressed. Email: srijambi@ gmail.com; \\ sri_rahayu@unja.ac.id
}

\begin{abstract}
Accountability of assets is an unfinished problem in almost all local governments in Indonesia. It is proved by the high number of audit findings from the State Audit Agency regarding asset management issues. The aim of this study is to analyze the implementation of the accountability of fixed assets of local government. The method used is qualitative method. Questionnaires and interviews were done for data collection. The respondents of the research are government officials and apparatus who are actively involved in managing regional assets. The result shows that the implementation of the legal and process accountability for fixed asset management in Jambi City is categorized as good.
\end{abstract}

Keywords: Fixed Assets, Local Government, Legal Accountability, Process
Accountability

JEL Classification: M41, M42, M48

\section{INTRODUCTION}

The government continues to make improvements in achieving good governance at central and regional levels. One of the ways to see the increase in good governance in terms of financial management is State Audit Agency (BPK) opinions for both central and regional governments. After twelve years, central government finally gained an unqualified opinion (WTP in Indonesian) in Central Government Financial Statements Year 2016 (Report of audit findings of State Audit Agency 2017 (LHP BPK 2017). There has been a $20 \%$ increase in the number of WTP in the central government ministries/agencies in the last two years. In 2016, only 65\% (56 central government ministries/agencies) gained WTP, while 30 of them still received opinion other than WTP. In Premilinary Unaudited Central Government Financial Report (LKPP in Indonesian) Year 2017, there are 75 central government ministries/agencies that obtained WTP and only 15\% (13) of them that obtained opinion other than WTP (BPK, 2015, 2016).

At local government level, of the 537 Preliminary Unaudited Local Government Financial Report (LKPD in Indonesian) Year 2016, the State Audit Agency gave WTP to 375 LKPD (70\%), Qualified Opinions (WDP in Indonesian) to 139 LKPD (26\%) and Disclaimer Opinions (TMP in Indonesian) to 23 LKPD (4\%). WTP was obtained by 31 of 34 provinces (91\%), 272 of 415 regencies (66\%), and 72 of 93 cities (77\%). Obtaining these opinions has exceeded regional financial performance targets in the area of strengthening local government governance or regional financial capacity 
improvement program as stipulated in National Medium-Term Development Plan Year 2015-2019 that are respectively $85 \%, 60 \%$, and $65 \%$ in 2019. Comparing it with the achievements in 2015, LKPD that received WTP increased by 12 percent from $58 \%$ (2015) to 70\% (2016). The increase in WTP indicated an increase in the quality of LKPD, thanks to the efforts of the regional government in improving to previous year's shortcomings (BPK, 2017).

Although there has been an increase in opinion acquisition, government organizations must continue to improve the accountability of financial management and the quality of their financial statements. LKPD must be able to prove that managed funds have been used and invested without financial waste or abuse (Said \& Jaafar, 2014). The use of public funds carried out by the local government is, one of them, realized in fixed assets. Fixed assets are regional non-financial resources and have the greatest value in financial statements (Sadjiarto, 2000). Fixed assets are the resources and assets of the state as a tool in the implementations of government operational activities. Good asset management will have a direct impact on regional financial management (Pangaribuan \& Sumini, 2010). If regional assets are managed effectively and efficiently, it will have an impact on effective and efficient financial management. In reality, however, there are still lots of regional fixed asset management that have not been accompanied by high accountability. One of the evidences is that there are still findings of regional asset management from the results of the BPK audit (BPK, 2017).

Some problems in asset management often faced by local governments are fixed assets that have no valid proof of ownership (such as certificates), incomplete administration of asset management in accordance with regulations, and the value of fixed assets recorded doesn't reflect the actual condition (BPK, 2016). These problems may not appear in the financial statements, but the disclosure of these problems will greatly influence the decision making by the authorities. The risk of the incomplete information will be the misleading in decision making.

Fixed assets are still being a cause of poor opinion on LKPD in Indonesia (Sujarwo \& Halim, 2013). In addition, the increasing number of Unqualified Opinion on LKPD has not been followed by the increased level of accountability in many Indonesian local governments. The development of accountability of performance in Regencies/Cities of 2017 in Indonesia was mentioned by Minister of Administration and Bureaucratic Reform in Yogyakarta on February 15, 2018. Regencies/cities received the CC category or below are 303 (63.80\%). Government agencies obtaining accountability scores below 70 potentially have budget inefficiencies. The higher the value of performance accountability, the higher the budget efficiency (Inspektorat, 2016).

The quality of disclosure and accountability for activities will affect the evaluation and control of the implementation of the activities. Sadjiarto (2000) and Ebrahim (2010) provided a definition of accountability as a responsible relationship between those who manage the entity and those who have formal power over the manager towards the acceptance and judgment of certain responsibility. An activity is said to have high accountability if it can be legally and morally accountable (Agustinus, 2012).

Public accountability is characterized by the provision of information and disclosure of the activities and financial performance of local governments to interested parties (Mardiasmo, 2004). Based on this definition, it can be concluded that government accountability in the management of regional fixed assets is the provision of information and disclosure of activities or asset management activities carried out by 
the government to interested parties, and such activities must be legally and morally accountable.

Accountability in the fixed asset management includes legal accountability and process accountability (Mardiasmo, 2004). Legal accountability is the accountability or responsibility of government (manager/steward) that is realized through the implementation of applicable regulations and laws. Process accountability is a form of accountability, which the procedures used in the management of fixed assets have been carried out correctly in accordance with the applicable regulations and involve measures in its implementation (planning, allocating, and managing).

Based on the explanation above, researchers aim the research on analysing the accountability of fixed asset management in the Local Government of Jambi City. In addition, this study also aimed to uncover obstacles and strategies to improve asset management accountability from the point of view of regional asset management apparatus. Fixed assets which are the focus of this research are Land and Buildings.

\section{METHODS}

This study used a qualitative method. In qualitative research, the author tries to be as close as possible to the informants to understand the context/background or the environment in which they face the problem of the research and qualitative research is axiologically not free of value (Creswell, 2014). Qualitative methods are used in order to achieve research's aim, that is, obtaining an overview of the accountability of fixed assets management carried out by the local government, in disclosing the reality and existing phenomena through direct interaction between researchers and informants as well as evidences and other related documents.

The informants of this study are the asset managers/stewards in Regional Financial and Asset Management Service (DPKAD in Indonesia). The data used are from the discussion through interviews, review of documents and questionnaires. There were 15 respondents/informants that are apparatus related to asset management. The indicator used to assess the implementation of legal accountability and process accountability in the asset management refers to the relevant regulations, that are, Minister of Home Affairs Regulation (Permendagri) No. 17 of 2007; Government Regulation (PP) No. 71 of 2010; Presidential Regulation (Perpres) No. 54 of 2010 which was amended by Presidential Regulation (Perpres) 172 of 2014; Government Regulation (PP) No. 27 of 2014 and Government Regulation (PP) No. 60 of 2008. Questionnaires have the choice of answers of "yes" and "no" that can reflect the implementation of a regulation. "Yes" has the value of 1 and "no" has the value of 0 .

The level of compatibility of the implementation was calculated by the percentage of the answers' value from the questionnaire. The total value obtained will be divided by the total criteria and multiplied by one hundred percent. This study uses percentage descriptive techniques. Firdaus and Ritonga (2018) stated that the percentagedescriptive-technique is a technique to calculate the level of compatibility by making a percentage of existing data, and then it will be described. The calculations were done as in the following formula:

\section{Level of compatibility $=($ Total value obtained $) /($ Total criteria $) \times 100 \%$}

Steps in carrying out percentage-descriptive-technique to determine the compatibility level of implementation of fixed asset accountability for land and buildings were conducted as follows: a) determining the criteria for legal and process accountabilities of Land and Buildings in accordance with applicable regulations. Legal 
accountability has several indicators, namely Planning and Budgeting; Procurement; Receipt, Storage and Distribution; Implementation; Administration; Utilization; Security and Maintenance; Assessment; Disposal of Fixed Assets; Transferring; Guidance, Supervision and Control; Financing; Claims for compensation. These indicators are in seventy-three questions. Process accountability is assessed by using a process dimension consisting of eight questions; b) Finding facts of compatibility through the questionnaire; c) Scoring the answers by giving value of 1 if it matches the criteria, and value of 0 if it doesn't; d) Adding up the total value/score obtained for both assets (Land and Buildings); e) Calculate the average percentage of compatibility level of the implementation; f) Describing and interpreting the obtained average percentage of compatibility level of the implementation.

The level of compatibility is used to determine the results of the evaluated implementation based on five criteria (Table 1). It refers to Firdaus and Ritonga (2018) with some modifications as follows:

Table 1. Criteria for compatibility level of the implementation of law accountability and process accountability

\begin{tabular}{lcl}
\hline Average & Criteria of compatibility & Criteria of implementation \\
\hline $100 \%$ & Very Compatible & Very Good \\
$75-99 \%$ & Compatible & Good \\
$50-74 \%$ & Fairly Compatible & Fairly Good \\
$55-49 \%$ & Not Compatible & Bad \\
$0-25 \%$ & Very Incompatible & Very Bad \\
\hline
\end{tabular}

Source: Firdaus and Ritonga (2018)

For analysing qualitative data, the interactive qualitative analysis steps were used. The steps are screening the sample, determining the theme, determining temporary conclusions and presenting (Rahayu, Ludigdo, Irianto, \& Nurkholis, 2015). Researchers can use each step by having an interaction. It means that it is possible to repeat a step from the data collection stage. Qualitative research provides an opportunity to be flexible enough to do it.

Validity test in this study was carried out by increasing persistence, negative case analysis, compiling a rich and solid descriptions of the results of the study (Sugiyono, 2015). Reliability test refers to dependability testing carried out by examining the entire research process (Firdaus and Ritonga, 2018). The credibility of qualitative data was examined using triangulation of data sources, namely comparing between data obtained from various sources (Rahayu, 2016).

\section{RESULTS AND DISCUSSION}

\section{Development of fixed assets in Jambi City}

Fixed assets must be managed properly because other than being used for operational activities and public services, they can also be a source of regional income. In addition, fixed assets become one of the benchmarks for local government performance as well. Fixed assets obtained from capital expenditure are always sought to be increased in number because they can be one of the boosters for regional economic growth.

Therefore, fixed assets become the focus of the Government of Jambi City. In the following figure, we are able to see the development of net fixed assets of the Government of Jambi City: 


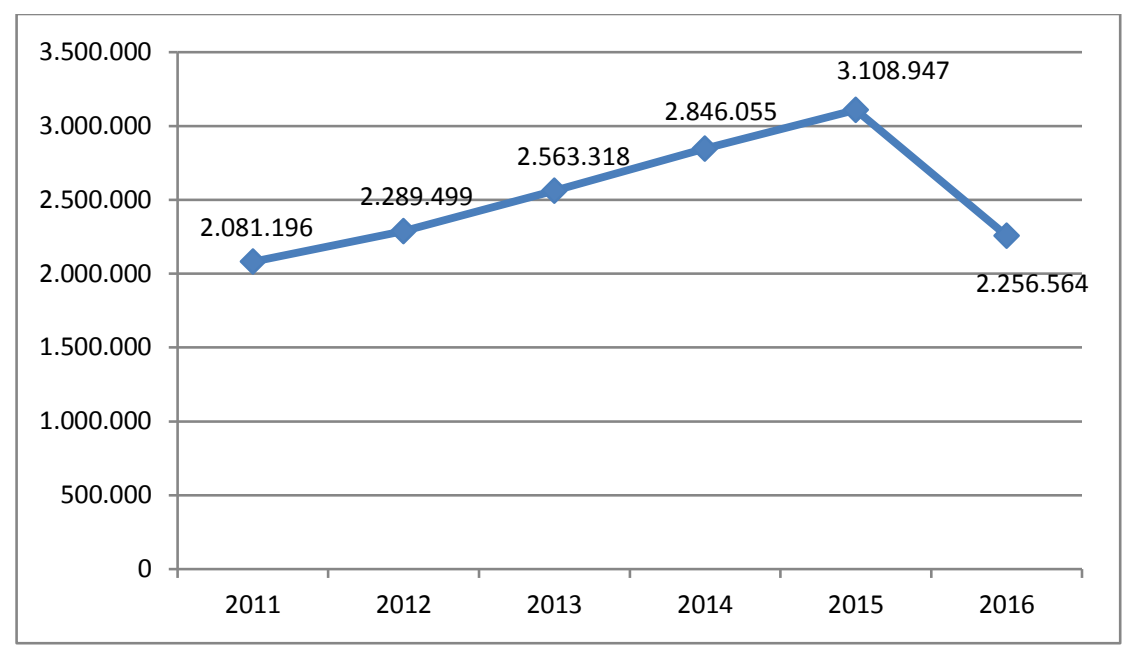

Graph 1. Growth/development of net fixed assets of Jambi City 2011-2016

The realization of fixed-asset budget increases every year and the decrease in net fixed assets from 2015 to 2016 are shown in the figure above because of the increase in the accumulated depreciation of fixed assets. Government of Jambi City has prioritized budget allocation for fixed assets. One consideration is that fixed assets are directly related to the needs of the community. Infrastructure developments such as roads, irrigation and bridges are the concern of the Government of Jambi City. Besides providing comfort for the community, it also aims to accelerate the economic growth of Jambi City.

As of December 31, 2016, the Government of Jambi City has 650 plots of land that were distributed over 27 Regional Work Units. Some of them are leased by Local Revenue Offices in the form of 43 locations of land to 40 tenants. In addition, there are also fixed assets (Land) in the form of public facilities in seven housing estates in Jambi City, such as playgrounds. Land experienced an increase in the balance sheet as of December 31, 2016 compared to the previous year. As of December 31, 2016, it shows that land worth Rp. 481,346,826,952,-, meanwhile the land worth Rp. 475,243,924,252,- per December 31, 2015. The realization of Expenditure for Land in 2016 was quite low at only $12.86 \%$. Out of a budget of Rp. 1,225,500,000, only Rp. $157,603,000$, was used. It has decreased considerably compared to 2015 's realization of land expenditure (reaching Rp. 2,381,288,000).

Buildings and plants are all buildings and plants obtained by the intention of being used in government's operational activities in a ready-to-use condition. Two types of owned buildings are buildings and monuments. The buildings consist of buildings used for work, residencies, towers, and rented kiosks. Monuments consist of historical buildings, memorials, control-point monuments, and traffic signs.

Buildings and Plants owned by Jambi City consist of parking lots, parks, arches, musholla (Islamic prayer building/room), nursing homes, water treatment, swimming pools, and offices. In the operational activities of public services, the Government of Jambi City still makes use of 27 buildings and plants which were built on land owned by Jambi Province. It means the Government of Jambi City uses the land in loan status. The existing buildings on that land include offices, schools, sub-district offices and urban-village offices. Loan status like this, should be clarified immediately through the asset grants between regions, so the ownership and presentation of assets in each region's balance sheet will be clearer and easier. 
Government of Jambi City also revealed in the notes of its 2016 financial statements, that there were fixed assets in the form of buildings lent to 4 public institutions. The amount of building and plant expenditure budgeted in 2016 amounted to Rp. $104,057,109,193$. $98.42 \%$ of the budget has been realized, which worth of Rp. $102,411,390,734$. The spending for building and plant has increased compared to the previous year of Rp. 60,129,512,749. It certainly affects the increase in building and plant assets presented on the balance sheet in those two years. The increase of building and plant assets as of December 31, 2015 reached Rp. 744,897,313,909.51 and as of December 31, 2016 amounted to Rp. 871,183,176,438.12,--

\section{Fixed assets accountability of Jambi City}

\section{Legal accountability}

Based on Permendagri No. 17 of 2007, it stated that one of the principles that must be implemented is accountability. The implementation of legal accountability for both fixed assets is in the "good" category. Legal accountability for buildings at 93.15\%. From 73 question items, 68 respondents answered "yes" on average and only 5 of them answered "no". Some implementations that are yet optimized are: 1) Indicator of Administration, especially the punctuality of reporting Region-Owned Land. The implementation of inventarization process of BMD (Region-Owned Property) every five years has not been implemented optimally. It is yet periodically carried out; 2) Indicator of Compensation Claims (TGR) especially for Exemption of TGR and Submission of TGR Objection related to findings of Region-Owned Land. Both items have not been implemented because every time there are audit findings related to the asset, it is being acted upon immediately by the authorities, and if it contains elements of TGR, it is immediately resolved; 3) Indicator of Security for protection carried out for Region-Owned Land. Security officers are not hired specifically for land. The protection of land has been carried out only by providing signposts for the ownership of the Government of Jambi City and fences.

Legal accountability and fixed asset regulations for Buildings have a better score than those of Land. The status of "good" on the implementation level shows the compliance of the Government of Jambi City with related regulations in managing the assets.

Legal accountability for Buildings is also categorized as "good" at $87.14 \%$. Of 70 question items from 13 indicators, an average of 61 respondents stated "yes" and only 9 respondents stated "no". Some implementations that are not yet optimized are: 1) Indicator of Administration for the punctuality for reporting Region-Owned Building, five-year Region-Owned Building inventarization process, and reporting on the use of Region-Owned Building. It shows that the punctuality of reporting and the periodic inventarization process are not optimal; 2) Indicator of Financing for evaluation conducted for financing that has occurred. The evaluation has been done but it has not been well documented.

Legal accountability relates to compliance with applicable regulations required in running an organization. Accountability of compliance with applicable laws and regulations must be considered in addition to transparency and responsibility (Shaoul, Stafford and Stapleton, 2012). Legal accountability in the management of fixed assets of buildings and plants, and of land in the Jambi City, has been good. It is proven by the absence of State Audit Agency's findings regarding compliance with regulations for these two assets. 
Especially for Land that consists of 663 plots of land, they come from various methods of acquisition, including purchases through spending on land and grants from various parties. Based on the disclosures in the 2015 financial statements, 315 plots of land do not have certificates. It means that 348 plots of land already have certificates. In 2016, the Government of Jambi City has increased the amount of certified lands, left 292 plots of uncertified land. The ownership certificate is important to be obtained immediately by the Government of Jambi City, for the legality of its fixed-assets.

\section{Process accountability}

The implementation of process accountability for Buildings, Plants, and the Land is categorized as "good". Implementation levels of process accountability for both assets are at the same number at $75 \%$. Some implementations for Buildings and Plants, that is yet optimized are: 1) Reward and punishment have not been implemented in managing buildings and plants; 2) Reporting has not been punctual; 3) Updated data regarding management cannot be obtained quickly.

As for Land, the implementations of accountability that are yet optimal are: 1) Reporting wasn't punctual; 2) Unsettled patterns of asset management concerning personal tasks.

The indicators above are not optimal on its implementation, one of which is due to the lack of on-line system starting from the procurement process of assets to the reporting of assets. So that changes in assets cannot be monitored any time. In addition, the implementation of some accountabilities of process has not been well documented.

Government of Jambi City has established accounting policies/regulations related to the accounting for fixed assets. Fixed asset is recognized if its future economic benefits can be obtained and its value can be measured reliably. The recognition of fixed assets is stated as reliable if the fixed assets have been handed over their ownership rights and or when the ownership has changed hands.

Fixed assets management by local governments in accordance with applicable regulations can be explained by the theory of stewardship. In the theory of stewardship, the manager/steward (regional assets steward) will behave in accordance with the principal interests (community). If there is a difference in principle, the steward of assets will try to act in accordance with the principal interests because the steward believes that the affairs has to be done to achieve organizational goals (Raharjo, 2006). Agency relationships with local governments are not as simple as with private organizations (Halim \& Abdullah, 2009). The apparatus is a man who is able to act with full responsibility, high integrity, trustworthy, and honest in carrying out the tasks given (Kaihatu, 2006).

Local governments are organizations in the public sector that have the responsibility to be able to provide and channel resources for the welfare of the people. Daily operational objectives are the optimization of public services for the community. The orientation in local governments is not related to economic relations. Economic relations are assumed to be relationships that are influenced by personal interests and profits (Aurelie \& Petrie, 2014).

\section{Problems in the implementation of fixed asset accountability}

There are several problems in increasing asset accountability:

1. The competence of asset manager is still low along with the changes in the government's accounting basis, and it affects asset management in the regions. Recognition and measurement, as well as assessment changes. Before 2015, several 
regions had not calculated the accumulated depreciation. Since the implementation of Government Regulation (PP) No. 71 of 2010, starting from the 2015 financial report, all local governments must use accrual accounting.

The use of accrual accounting requires both human resources and system to be used to manage the assets. Human resources who are knowledgeable about accounting are needed in order to understand, when an asset must be recognized, how much assets are measured and how assets are assessed/measured. Jambi City has sufficient reliable human resources in asset management in the Government of Jambi City, posted in DPKAD. But in SKPD, accrual accounting is not well understood yet. Human resources at SKPD still have an understanding of the cash base towards accruals, even some of them still have a cash base mindset.

2. The limited number of asset manager.

There are one head of division and 14 employees ( 8 civil servants and 6 non-civil servants) working in Division of Assets in DPKAD. These stewards of assets are also supported by the asset management division in all SKPD. The number of the officers is considerably small compared to the number of assets in Jambi City, especially with the high demands of asset management. They have to do planning, analysis, monitoring of implementation, combined inventory of all assets of the city, and analysis to optimize asset utilization. Technology is needed to support asset management with this limited number of management personnel.

3. The use of assets between regions. Jambi City is the capital of Jambi Province. One of the consequences related to assets is the phenomenon of using Province's assets by the Jambi City in its operational activities. Similarly, there are several assets of Jambi City that are utilized by other institutions, even by vertical institutions.

4. The optimization of asset management system. Government of Jambi City continues to make improvements in the management of its fixed assets. Asset Mutation in Regional Organizations cannot be monitored at any time by the Division of Asset, so that Region-Owned Property reports are not up-to-date at any time.

5. Assets as a source of regional income have not been optimal. Almost in all local governments in Indonesia, they are only using fixed assets in accordance with the objective of government organizations that is public services. One of the consequences of regional autonomy is not only the granting of authority in spending / expenditure management, but also the requirement of being more independent in its finances. One of the regional independence's indicators is the ability to finance regional expenditures from its source of local revenue/income. One opportunity to increase local revenue is by optimizing the use of assets.

\section{Strategies for improving accountability of fixed assets of Jambi City}

Several strategies that should be implemented by Government of Jambi City to improve its fixed asset accountability are:

1. Increasing the quantity and quality of regional asset managers/stewards. Activities such as trainings and technical guidance, also promotions need to be carried out for regional asset stewards, both those in DPKAD and in SKPD. The limitation of the human resources was noticed by the Government of Jambi City, so that in the process of asset inventarization was assisted through mentoring by Jambi Province Representative of Indonesia's National Government Internal Auditor.

2. Optimizing asset management system using an integrated online system, starting from asset planning, implementation of procurement, evaluation, disposal to 
reporting of fixed assets. So that every asset mutation will be known, including at SKPD level.

3. Improving asset management. Planning of fixed assets that should be done by Government of Jambi City is the one based on $5 \mathrm{~W}$ (What, Who, Where, When, Why) and $1 \mathrm{H}$ (How). In 2016, the Government of Jambi City conducted an inventarization of all fixed assets. This inventarization is carried out by the inventory team based on the Decree of the Mayor of Jambi Number 304 of 2016. In the inventory management process, Government of Jambi City cooperates with Jambi Province Representative of BPKP.

4. Optimizing the use of assets. Regional assets in the form of land, buildings and plants, and other fixed assets have the potency to be used as a source of regional income.

\section{CONCLUSION AND RECOMMENDATION}

\section{Conclusion}

Legal accountability and process accountability of fixed assets in the Jambi City have categorized as good. The low implementation of process accountability is partly due to the lack of an integrated online system, starting from the procurement of assets to the reporting of assets. So that division of the asset has not been able to monitor at any time changes in assets of Jambi City. This study has limitations, such as combining several processes in some questionable items.

\section{Recommendation}

Government of Jambi City should increase the accountability of its fixed assets by improving the competence of asset managers. One of the most effective strategies is the implementation of an integrated online system in asset management, starting from planning, and implementation to reporting of regional fixed assets. In the future, researchers can expand the respondents of the research to all assets managers in SKPD and add the elements of accountability to be analised.

\section{REFERENCES}

Agustinus, J. (2012). Kajian Fenomenologi kinerja keuangan dan akuntabilitas pengelolaan dana otonomi khusus sektor pendidikan di Provinsi Papua. S3, Universitas Brawijaya, Malang.

Aurelie, \& Petrie, U. (2014). The transformative effect of top management governance choices on project team identity and relationship with the organization - An agency and stewardship approach. International Journal of Project Management, 32, 1358-1370.

BPK, R. (2015). Laporan Hasil Pemeriksaan BPK RI Tahun 2015: Badan Pemeriksa Keuangan.

BPK, R. (2016). Laporan Hasil Pemeriksaan BPK RI Tahun 2016: Badan Pemeriksa Keuangan.

BPK, R. (2017). Ikhtisar hasil pemeriksaan semester II BPK RI tahun 2017. Retrieved from 1507002855.pdf.

Creswell, J. W. (2014). Qualitative inquiry \& research design: Choosing among five approaches. Thousand Oask, London, New Delhi: Sage Publication.

Ebrahim, A. (2010). The many faces of nonprofit accountability. 
Firdaus, M. A., \& Ritonga, I. T. (2018). Analisis artikulasi laporan keuangan pemerintah daerah. Jurnal Akuntansi \& Akuntabilitas Publik, 1(1), 68-87.

Halim, A., \& Abdullah, S. (Producer). (2009, 12 Juni 2015). Hubungan dan masalah keagenan di pemerintah daerah: Sebuah peluang penelitian anggaran dan akuntansi. Retrieved from http://www.bppk.depkeu.go.id/

Inspektorat, P. J. T. (Producer). (2016). Transformasi fungsi audit intern pemerintah: Meningkatkan kapabilitas APIP. Retrieved from http://inspektorat.jatengprov. go.id/2015/po-content/po-upload/4.\%20\%20DEPUTI\%20PKD\%20-\%20Dada dng\%20K.pdf

Kaihatu, T. (2006). Good corporate governance dan penerapannya di Indonesia. Jurnal Manajemen dan kewirausahaan, 8(1), 1-9.

Mardiasmo. (2004). Otonomi dan manajemen keuangan daerah. Yogyakarta: ANDI.

Pangaribuan, \& Sumini. (2010). Modul pokok pokok pengelolaan barang milik daerah. Paper presented at the Pusdiklat Kekayaan Negara dan Perimbangan Keuangan.

Raharjo, E. (2006). Teori agensi dan teori Stewardship dalam perspektif akuntansi. Fokus Ekonomi, 2(1), 37-46.

Rahayu, S. (2016). Institutionalization process of SOA funds budgeting at basic education institutions in Indonesia. Research Journal of Finance and Accounting, 7(4), 201.

Rahayu, S., Ludigdo, U., Irianto, G., \& Nurkholis. (2015, 17-18 September 2015). Budgeting of school operational assistance fund based of Gotong Royong. Paper presented at the 2nd Global Conference on Business and Social Science, Bali.

Sadjiarto, A. (2000). Akuntabilitas dan pengukuran kinerja pemerintahan. Jurnal Akuntansi \& Keuangan, 2(2), 138-150.

Said, \& Jaafar. (2014). Accountability in government linked companies: An empirical finding. Procedia-Social and Behavioral Sciences, 145, 294-299.

Sugiyono. (2015). Metode penelitian kuantitatif, Kualitatif dan R\&D. Bandung: Alfabeta.

Sujarwo, H. N., \& Halim, A. (2013). Analisis inventarisasi aset tetap pada pemerintah Kabupaten Bantul. Jurnal Program Magister Akuntansi Fakultas Ekonomika dan Bisnis, Universitas Gadjah Mada. 